\title{
THE ECONOMIC CAPACITY OF THE MOST DEVELOPED NATION: NORWAY
}

\author{
Luca DIACONESCU* \\ University of Oradea, Doctoral School of Geography, 1 st, Universității St., 410087, Oradea, \\ Romania, e-mail: diaconesculuca@yahoo.ro
}

Citation: Diaconescu L. (2019). The Economic Capacity of the Most Developed Nation: Norway. Revista Română de Geografie Politică, 21(1), 24-28. https://doi.org/10.30892/rrgp.211103-326

\begin{abstract}
Norway has been a period of the world's most developed nation, remaining at the top five in the world. The heavily exploited natural resources and well-engineered economic processing activities have created a prosperity paradise from Norway, surpassing economic or military even states with a population of 40 times more.
\end{abstract}

Key words: production, natural resources, population, geopolitics, first place

\section{INTRODUCTION}

Norway has a population of only 5.3 million people, as well as the population of German cities such as Berlin, Hamburg, Frankfurt, Stuttgart or Essen, under half the population of the French city of Paris or a quarter of the Turkish city of Istanbul (Diaconescu and Lung, 2018; Diaconescu, 2016; Diaconescu, 2018a). It is a low population in 2018, only 119 in the world with the most populated states, a very low population if we take into account that every five years the population of some states increases by 5 million inhabitants such as: Niger, Afghanistan, Mozambique, Angola, Sudan or Iraq, or in only three years, such as the states: Uganda, Mexico, the Philippines or Bangladesh, in only two years as in the states: USA, Ethiopia or DR Congo. Nigeria's population grows every year with 5 million inhabitants and the population of India with 15 million people (Diaconescu, 2017).

Nothing stands on its surface not much better, ranking 62 in the world, much of this area is at high altitudes and in polar and sub-polar regions very cold (Soft, 2009 p. 84-85). For those population density remained only 15 inh. $/ \mathrm{km}^{2}$, low population density than at the Earth 51 inh. $/ \mathrm{km}^{2}$, the world 209 barely ranks among countries with the highest density of population, with the in 2018, 112 states with a density of more than 100 places $/ \mathrm{km}^{2}$, of which 73 with over 200 places $/ \mathrm{km}^{2}$ (Woldometers.info, 2018). Basically, the surface does not 
give Norway an important geopolitical value and the number of inhabitants is even more disadvantaged. Despite these lows, Norway managed through an efficient exploitation of its rich resources, a system of processing raw materials better tech, to win a valuable geopolitical, being one of the great nations of the world now, a national economy that ranks $29^{\text {th }}$ in the world, surpassing any of the states on the continent of Africa and the $13^{\text {th }}$ in Europe $\left(26^{\text {th }}\right.$ place among the most populated European countries).

\section{PRODUCTION AND PROSPERITY}

Unlike many countries in the region, such as Ireland, the Netherlands, Sweden and Finland, whose residents have worked hard for economic growth of their nations, the five million Norwegians have come to exceed the economic power, countries like: Romania with 20 million workers, Colombia with 49 million, Philippines with 106 million, Bangladesh with 166 million, Nigeria with 196 million or Pakistan with 201 million inhabitants, helped by natural factors (Stașac and Stupariu, 2010).

Norway has an area of $323,000 \mathrm{~km}^{2}$, reaching with all the islands held at $386,000 \mathrm{~km}^{2}$ (slightly larger than the size of Germany or Japan) whose territory is home to a population of approximately 5.3 million inhabitants, of which nearly 3.0 million are the country's labor force (Sehic, 2008, p. 80). A quarter of the country's surface is covered by 8 million cubic meters of forest, which has developed a strong pulp and paper industry and is also a major timber producer. Agriculture is practiced in the south, where they raise cattle and growing potatoes and oats, which occupies $2 \%$ of the labor force and on which has developed food industry.

Being a predominantly mountainous country with a rainy climate stretching across the Atlantic-Arctic rivers, the rivers are short, fast and flowing. The hydro-energetic potential was well appreciated, reaching a share of $96 \%$ of total energy (the first in terms of hydro power production in Europe), which is 148 million $\mathrm{GW} / \mathrm{h}$ being ranked 29 among the countries with the highest the production of electricity on Terra (one and a half times the production of Romania), reaching the second largest electricity per capita in the world (after Iceland), with $30,000 \mathrm{~kW} / \mathrm{h}$, recalling the fact that this energy has the lowest cost of production compared to thermoelectric or nuclear energy (Diaconescu, 2018b). Based on this, it imports large quantities of bauxite from which it obtains aluminum (the $7^{\text {th }}$ aluminum producer on Terra) which exports it to Sweden, using it in the aerospace industry. Although it is only $62^{\text {th }}$ in the world as an area, it is an elongated and narrow country, ranked $7^{\text {th }}$ in the world and the first in Europe after the length of the coastline, which has 22,000 km (more than the distance between the North Pole and the South Pole) on a distance from the north to the south of just $2,600 \mathrm{~km}$, due to both the famous fjords and the 150,000 islands (besides the islands near the shore, also holds: The North Svalbard Archipelago, Jan Mayen Island near Greenland, the island Bouvet in the southern Atlantic Ocean, claiming much of the Antarctic continent: Queen Maud's land of 2.5 million sq $\mathrm{km}$ ), and in the south-eastern Pacific Ocean or the South Ocean holds the island of Peter I (Taylor, 2010, p. 54; Gâștestescu and Cioacă, 2013, p. 105-106, 328; Gifford, 2005, p. 150-151). 


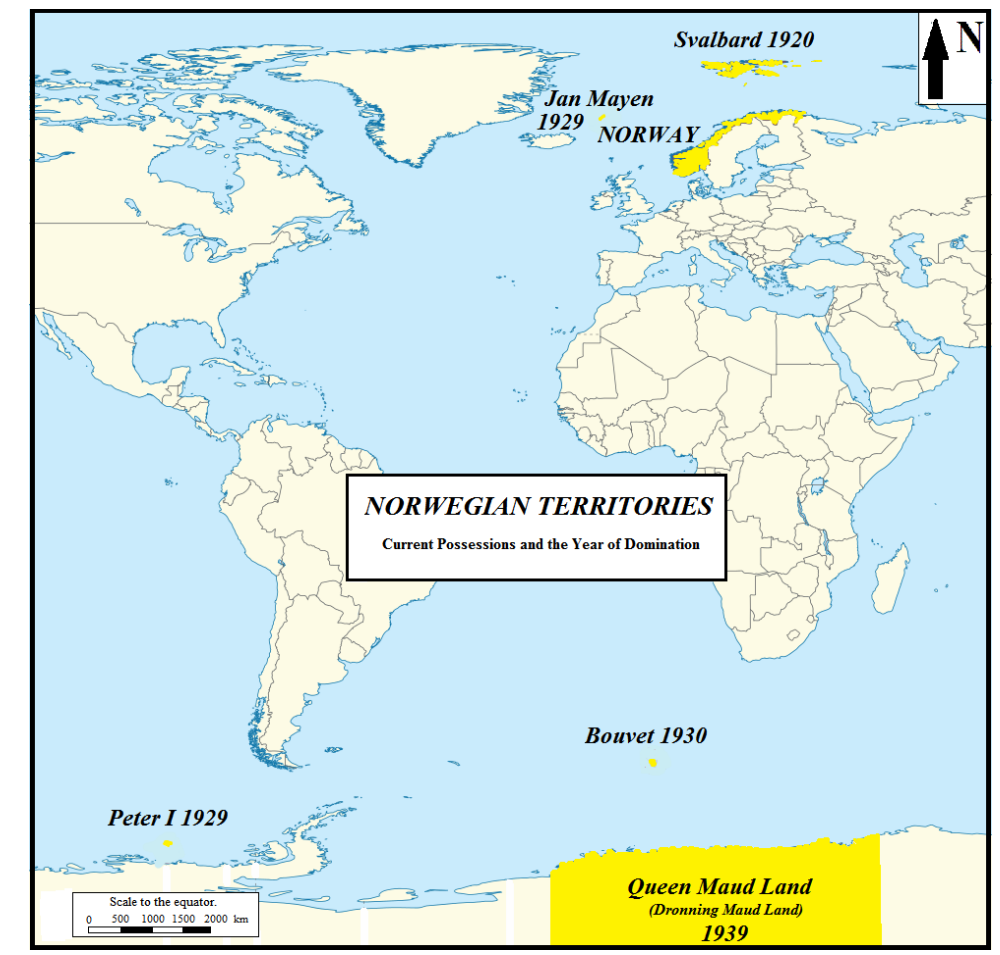

Figure 1. The territory of Norway and all possessions owned by it Source: MCMXC, 1990; Gardner and Berenson, 1989

Due to the extended seaside, it has developed the shipbuilding industry, currently holding $10 \%$ of the world's oil fleet and among the first 15 states in the maritime fleet as well as the sixth ship-exporter worldwide, with which it also transports other states or regions of the same state that do not have naval capacity, playing the role of a taxi of the seas. The surface of the territorial waters reaches $800,000 \mathrm{~km}^{2}$ for the Exclusive Economic Zone and the total area of the fishing area is $1,900,000 \mathrm{~km}^{2}$, which is six times the area of Norway. The fish richness of these waters led to fishing with their own vessels, Norway exporting 12.0 billion tonnes of fish in 2017 (the second after the EU and China), while developing the canned fish industry which substantially increases its profit, from seas and seas collecting algae or shells. However, marine areas are far too large and rich in fish, so it gives fishing rights to other states (such as Poland, which are sufficient Baltic Sea waters to catch up with domestic needs), a practice that brings extra income.

Holding 8 million hectares of pine forest mostly with great financial value, which operates eight million cubic meters, and in the south is one million hectares of arable land well cultivated (Anton and Peness, 2008, p. 39, 57).

In 1960 oil reserves were discovered in the North Sea (estimated to be 0.9 billion tonnes, the second in Europe as reserves after Russia), reaching a production of 1.7 million barrels per day (the second producing in Europe after Russia, the $15^{\text {th }}$ on the Terra and similar to the production of states such as Algeria or Iraq, whose income is predominantly from the sale of oil. The same amount is recorded by the United Arab Emirates, which built its oil revenues Among the most prosperous nations, buildings in the cities of Abu Dhabi and 
Dubai are well known, which exceeds more than three times the quantity exploited by Romania and twice the production of the third producer in Europe, Great Britain (Roberts, 2008). Oil exports reach 1.4 million barrels per day, ranking $13^{\text {th }}$ among world exporters (5th place before 2010). Natural gas reserves rank the country in $19^{\text {th }}$ place, with annual production of 110 million cubic meters, being the world's $7^{\text {th }}$ largest producer (the world's fifth in 2008) and a production equal to all EU countries (Peptenatu et al., 2005; Neguț et al., 2009, p. 69-71). Exports of natural gas reach over 100,000 million cubic meters, being the third largest exporter after Russia and Qatar. Norway ranks $11^{\text {th }}$ among the countries with the largest oil reserves per capita worldwide and ranked first in Europe and the natural gas reserves per capita rank the northern state on the $7^{\text {th }}$ place in the world and the first in Europe. These quantities of oil and gas make Norway the main export partner of the EU countries in their struggle to get out of dependence on oil and gas. Norway has developed many of its other wellknown industries by processing textiles, chemicals, mining or metals, from which the production of foundry steel equals Japan's production and surpassed only by Russia and Germany in Europe. With more than $70 \%$ of the population with higher education, it has developed innovation centers, and Oslo is a highly respected financial and decision-making center in the world, being one of the main cities in the organization of international congresses, Norway being also a large data market (Bonnet, 2000, p. 145, 152). Tourism comes as a financial surplus, with the 3-5 million visitors a year, with the Lillehammer winter resort known (Negut,, 2004, p. 85-86). All these riches that are found both on the continent and on the islands or in the territorial waters, which are well exploited and besides that processed and exported as goods (not as raw material), as well as the development of an industrial capacity that even requires imports of raw materials to be processed, plus top industry that is known to be among the most profitable industries, all of which were made by only 3.0 million workers, in a country where winter brings sunny days less than 3 hours, the relief is injured and rainfall and fog are at home (Matei et al., 2005, p. 349-351).

\section{CONCLUSIONS}

There is a natural curiosity of any inhabitant of a poor or middle-income country, wondering what the economic development of some western states that have per capita income and over 50 or 100 times the income of their own country. Norway is such a curiosity that Gross Domestic Product per capita reaches the colossal amount of 80,000 US dollars in a year, averaging nearly 7,000 US dollars per month. By doing a brief analysis of the main natural resources exploited, the added value of the finished products, the industrial and agricultural quantity, compared to the only 3 million people trained in the workforce, there is an enormous work capacity, worthy of a state's production force over 100 million people, not just 5.3 million as the total population of Norway.

The amount of natural resources exploited as well as their processing, creating additional value (compared to many other states selling low-priced raw materials, without interfering at all with its processing) makes Norway a worldwide mega-industrialist, comparable to the economic power of in very populated nations such as Nigeria or Pakistan, each have 40 times more population compared to the Norwegian people. In addition to these revenues, Norway having excess energy resources has led to a policy of lowering prices for the population, electricity, heat and fuel at the pump, making life even more prosperous for its 
own people. In addition to the economic potential of its energy or fish stocks, the naval fleet or its island territories extending to the southern Atlantic and Pacific Oceans, Norway also invests in the military arsenal (US $\$ 7$ billion a year, a budget of almost equal to the military expenditures of Romania) being 36 military power of the world, comparable to the strengths of some states such as Argentina, the Netherlands or Mexico, and surpassing: Romania, Nigeria, Colombia, Denmark, Finland or Portugal, all of which to one of the most known and respected nations on the Earth, with geopolitical and economic importance far above the demographic potential of only 5.3 million inhabitants.

\section{REFERENCES}

Anton, A. (trans.), Peneș, D. (trans.), (2008). Atlasul lumii: enciclopedia geografică a familiei: Vol. I: Geografica (The Atlas of the World: Geographical Encyclopedia of them Family: Vol. I: Geografica), Editura Erc Press, București.

Bonnet, J. (2000). Marile Metropole Mondiale (Great World Metropolises), Editura Institutului European, Iaşi.

Diaconescu, L. (2016). Cities Versus States: Demographic Evolution. Geographica Timisiensis, 25(1).

Diaconescu, L. (2017). Global Competition Between North and South. Revista Română de Geografie Politică, 19(2), 103-115.

Diaconescu, L. (2018a). The Development Center and the Progress of the World History and Perspectives. Revista Română de Geografie Politică, 20(1): 17-29.

Diaconescu, L. (2018b). Geopolitics of the Oceans: The Demographic Influence in the Separation of Powers. Revista Română de Geografie Politică, 20(2): 75-85.

Diaconescu, L., Lung, M.S. (2018). Power of big cities. Revista Română de Geografie Politică, 20(2): 67-74.

Gardner, J.L., Berenson, R.J. (1989). Atlas of the World, Reader Publishing, with Digest, London.

Gâștescu, P., Cioacă, A. (2013). Insulele Terrei (The Terrestrial Islands), Editura CD Press, București.

Gifford, C. (2005). Geografia: enciclopedia pentru întreaga familie (Geography: Encyclopedia for the Whole Family), Editura Teora, București.

Matei, H.C., Neguț, S., Nicolae, I., Malița, M. (2005). Enciclopedia statelor lumii, (Encyclopedia of the World States), Editura Meronia, București.

MCMXC (1990). Grand Atlas Geographique et Encyclopedique, Instituto Geografico de Agostini, Paris.

Neguț, S., Vlăsceanu, G., Bran, F., Popescu, C., Vlad, L.B., Neacșu, C.M. (2009). Geografie economică mondială (World Economic Geography), Editura Meteor Press, București.

Neguț, S., (2004). Geografia Turismului (Geography of Tourism), Editura Meteor Press, București.

Peptenatu, D., Drăghici, C., Cepoiu, L.A. (2005). Geografie economică mondială, Ediția a II-a (World Economic Geography, 2 $2^{\text {nd }}$ Edition II), Editura Universitară, București.

Roberts, P. (2008). Sfârșitul petrolului (Oil End), Editura Litera Internațional, București.

Sehic, D. (2008). Atlas geografic: Europa (Geographic Atlas: Europe), Editura România Liberă, București.

Soft, G. (tra.) (2009). Marele Atlas Ilustrat al Lumii (The Great Illustrated Atlas of the World), Editura Litera, București.

Stasac, M., Stupariu, M.I. (2010). The external migration dynamics of the Romanian population at the end of the XX century and beginning of the XXI century determined by change of residence. Analele Universității din Oradea, Seria Geografie, 20(1): 86-91.

Taylor, J. (2010). Marele Atlas Ilustrat al Mărilor (The Great Atlas of the Seas), Editura Litera Internațional, București.

Woldometers, real time world statistics: www.worldometers.info, last accessed, June, 2018.

Submitted:

January 15, 2019
Revised:

March 02, 2019
Accepted and published online: April 02, 2019 